\title{
A few thoughts from a museologist with a business degree
}

\section{PÓRA BJÖRK ÓlAFSDótTIR}

In recent years museums worldwide have been going through changes, some subtle and some more evident. Those who work in the museum sector see these changes in a different light than those who visit the museums. The visitors observe the museum's activities, through exhibitions, in social media, through research, in publications and through events etc. However, museums also communicate to the public with the stance they take in social context.

I am participating in the museum sector from an angle I find interesting. My present job is at a governmental institution, The Museum Council of Iceland, which supervises various museum activities from a professional viewpoint. The Council discusses proposals on the accreditation of museums, it lays down conditions and standards in museums, reviews museum premises, including accessibility standards and safety issues, monitors standards for cataloguing systems and the accreditation of such systems. The Council also provides, on request, an opinion or suggestions, for disposal or deaccession of museum objects and an array of other responsibilities. Iceland have, in the beginning of 2018, a total of 46 accredited museums and six other state-owned museums, including three principal museums. Those museums vary immensely in size and scope, from minuscule rural museums with one or two staff members to grand museums who run many exhibition halls with staff of eighty or more. Regardless of size all the museums are run by the same principle, to work according to the ICOM Code of Ethics and to meticulously attend to the full scope of all fundamental components of professional museums.

Many experts in the museum sector agree that, in general, we have observed a growth of professionalism in museum activities over the last years in those "hidden" aspects of museum work, the aspects which the visitor cannot see. Throughout the last few years there has been more focus applied to new thorough collection policies and registration is becoming more standardized and scrutinized through a joint registration system, which is in use in approximately 85 per cent of accredited museums and state-owned museums. ${ }^{1}$ More consideration is now given to conservation of the museum collection, i.e. accredited museums undergo an inspection from the Council which is enforced by a conservator, a service which many of the smaller museums haven't been able to utilize due to lack of financial resources. Overall it can be stated that the museum staff's general knowledge concerning the importance of proper conservation methods is increasing. More museums are partaking in collaboration projects, both with various institutions locally and also internationally. Many of these collaborations have an exhibition as a final goal, but increasingly these collaborations are 
138 also aimed at research, often with an exhibition angle. By and large, it would be positive if Icelandic museums would be able to increase their emphasis on research in museums irrespective of its impact on exhibition possibilities. It is evident that The potential of exhibition and communication has grown exponentially during the last decades. Digital possibilities are virtually endless when it comes to finding new ways to revolutionize museum activities, capital, or the lack of, apparently being the only limit. But the greatest technical innovation revolutionizing the way museums can interact with their visitors and audience is the rise of social media, which in most cases should not drain any museums' budget. Even though museums try to participate in this social media age, they are often hindered by a lack of knowledge on technical matters and how to grab the interest of the audience. The generation gap is not working in the museums' favour, even though most of the museum staff are aware of, and use social media.

A key factor in the increasing professionalism within museums operations is the growth of professionals working in the museums. Museology as academic field contributes greatly to these changes by advocating and teaching professional practice in museums, as more educated museologists are populating the museum workforce steadily. In Iceland we have seen an increase in academic debate and dialogue within the sector in recent years, one of the main reasons being, without doubt, the Museology program at the University of Iceland. The department was established in 2009 and the museums in Iceland have benefited immensely from the addition to the academic upbringing of the museum's employee pool. Apart from graduates from the University of Iceland we see many specialists who have graduated from universities and colleges all over the world, contributing to our growing museum sector with international expertise.

These changes in recent years can also be experienced from the visitors viewpoint. Museums are taking the initiative to approach some of society's most difficult issues of today, i.e. displacement of people due to war, famine or persecution. This could be witnessed at the International Museum Day in 2017 where the theme was Museums and contested histories: Saying the unspeakable in museums. Many museums last year took this theme to heart and through exhibitions tried to challenge the conventional "truth" of history, for example regarding gender and ethnic issues. Exhibitions are exploring beyond the familiar history of the authority of wealthy males to understand all aspects of the society. In Iceland it can be seen through some of the recent exhibitions and in those in the making. such as the Vestfirdir Museum's recent exhibition, "I was never a child", ${ }^{2}$ which focused on the life of a working woman in the first decades of the twentieth century. This can also be seen at the exhibition, "Kvinnorna", at the Vasa Museum in Stockholm. ${ }^{3}$

Museums are living organisations. They observe the changes in our societies and evolve with time. Many of them strive to be brave cultural institutions that take a stance on important social issues and their intensions are to be inclusive and accessible. Museums are entities in an ideal position to take such initiative.

\section{Notes}

1. The Museum Council of Iceland have been collecting statistical information on accredited museums for many years, these assertions are based on those statistics. Some statistical information is published in the Council's Annual Reports. 
2. About the exhibition, from the website of

Byggðasafn Vestfjarða, retrieved 8 March 2018:

https://www.nedsti.is/actual_exhibition_in_the museum/

3. About the exhibition, from the website of Vasa Museet, retrieved 8 March 2018: https://www. vasamuseet.se/utstallningar/kvinnorna2

Póra Björk Ólafsdóttir,

Managing Director, Museum Council of Iceland thora@safnarad.is

Gimli, Loekjargötu 3

I-101 Reykjavik, Iceland

https://safnarad.is/ 